\title{
Estimating Effectiveness of the Control of Violence and Socioeconomic Development in Colombia: An Application of Dynamic Data Envelopment Analysis and Data Panel Approach
}

\author{
Alexander Cotte Poveda
}

Accepted: 27 November 2010/Published online: 29 December 2010

(C) The Author(s) 2010. This article is published with open access at Springerlink.com

\begin{abstract}
This paper develops an index to evaluate the level of effectiveness of the control of violence based on the data envelopment analysis approach. The index is used to examine the grade of effectiveness of the control of violence at the level of Colombian departments between 1993 and 2007. Comparing the results across Colombian departments, we find that the majority of departments show improvement in their scores of effectiveness. A second stage of the regression model reveals that departments with a higher gross domestic product and higher education and employment are more effective in the control of violence, whereas departments with higher political violence, unemployment rates, unsatisfied basic needs, a displaced population, and hectares cultivated with coca show lower effectiveness in the control of violence. All these findings are of particular interest in the formulation and development of policies against violence, taking into account that organised forms of violence, such as drug trafficking, impede the adequate effectiveness of its control. Moreover, violence decreases social investments, generating alterations in social services that produce long-run deterioration in faith in the government's ability to govern, which should become an incentive to further violence.
\end{abstract}

Keywords Control of violence - Economic development - Effectiveness ·

Data envelopment analysis · Colombian departments

\section{Introduction}

Violence comprises of the use or threatened use of weapons to inflict injury, death or psychosocial harm, which undermines development. The human costs of violence are farreaching. It destroys lives and livelihoods, interrupts access to education, health and social

\footnotetext{
A. Cotte Poveda $(\bowtie)$

Department of Economics, University of Göttingen, Platz der Göttinger Sieben 3, 37073 Göttingen, Germany

e-mail: alexcotte@yahoo.com
}

\section{A. Cotte Poveda}

Faculty of Accounting and Administration, University of La Salle, Cra. 2 No. 10-70, Bogota, Colombia 
services, reduces social and human capital by sowing fear and insecurity, and results in high economic costs from years of lost productivity. Violence can induce large-scale displacement, restrict mobility, reduce investment and access to credit and trade, and contribute to the growth of illicit markets and power structures. It can also undermine governance and state stability, while creating or taking root in under-governed spaces. ${ }^{1}$ Violence is a source and result of a range of risk factors such as horizontal inequalities, ${ }^{2}$ poverty, socio-political exclusion and governance challenges (OECD 2009). In this context, violence has become an obstacle to the development of countries.

Violence is often restricted to specific geographic areas of a region, country, state, department or municipality. While certain areas of a country or city may operate normally, others can suffer from acute levels of violence. Peripheral, marginal and historically neglected regions such as border areas and city slums are often under-governed and vulnerable to the growth of informal and/or predatory power structures (Greene and Bourne 2005) like the guerrilla-dominated areas of southern Colombia and the urban shantytowns of Sao Paulo (Brazil).

In recent literature, violence has been studied using different methods and approaches. Collier and Hoeffler (2004) investigates whether the socio-economic determinants of homicide and civil war are similar and then explores potential inter-relationships between their using ordinary least squares estimation (OLS), indicating that higher homicide rates do not increase the risk of war but that civil wars generate a legacy of increased postconflict homicide rates. WOAT (2005) analyses the trends between incidents of violence and socio-economic inequalities at the macro and micro level using empirical analysis of the correlation between social and economic inequalities and violence, finding that socioeconomic inequality variables are explanatory in analysing variations in the level and type of violence at both the micro and macro levels. Burgoon (2006) develops arguments and evidence on how social policies affect terrorism and violence through both cross-sectional and pooled time series cross-section estimation, demonstrating that social welfare policies not only may serve redistributive or developmental goals but should also be a part of strategies to combat terrorist violence. An important difference between our analysis and these studies is that we use second stage data envelopment analysis (DEA) efficiency analyses in the context of control violence.

Boix (2008) applies an integrated analytical model that considers both the motives and the opportunities for violence from the perspective of states and rebels, using a multivariate analysis of the factors influencing civil wars, guerrillas and rebellious actions across the world in contemporary times. He finds that systematic and organised violent conflicts are most likely in economies where inequality is high and wealth is mostly immobile, that is, in societies where those worse off would benefit substantially from expropriating all assets. Bodea and Elbadawi (2008) analyse the economic growth impact of organised political violence through a quantitative model of violence, predicting probabilities of aggregate violence and demonstrating that, under plausible assumptions about risk aversion during times of conflict, the overall effects of organised political violence are likely to be much

\footnotetext{
${ }_{1}$ Under-governed areas include those lacking the presence of formal state structures/representatives. In fact, most "under-governed" areas feature some form of traditional or alternative governance institutions, leaders and practices. These alternatives are often regarded as being more legitimate and representative than the central government in the eyes of the local population. However, alternative governance structures can also be coercive and exploitive (while lacking legitimacy), especially when authority is based on enforcement by armed non-state actors linked to criminal enterprises (Clunan and Trinkunas 2010; Lamb 2007).
}

2 "Horizontal inequalities" defines to inequalities among groups living in the same society (Stewart 2008). 
higher than its direct effect of capital destruction. Our analysis differs in that we focus on structural risk and proximate risk factors to explain the variations in control of violence.

In the Colombian case, several studies have used different approaches to analyse the violence and its results. Martínez et al. (2001), using data from the 1990s, determine a weak role for poverty but none for inequality on violence. Sanchez and Nuñez (2001), with data between 1980s and 1990s, find that poverty, inequality and social exclusion explain only a small fraction of the homicide rate. Bourguignon et al. (2002), with data from the 1980 s and 1990s, show that only a certain fraction of the income distribution, namely, the percentage of people below $80 \%$ of mean income, is related to property crime. Rubio (2001), analysing a cross-section of Colombian municipalities for different yearly intervals since 1987, shows that traditionally important determinants of guerrilla presence at the community level, such as inequality, wealth and education, lose their explanatory power during the 1990s. Holmes et al. (2007) examine the traditional political and economic factors that have been purported to explain the prevalence of insurgency at the sub-national level in Colombia, finding that guerrilla violence is positively associated with exports; higher levels of insurgency are associated with low levels of gross domestic product (GDP) per capita; and guerrilla violence emerges in the context of a weak state presence. Cotte (2007) finds that socioeconomic features of every Colombian region have affected the economic growth dynamics and that productive factors and violence have effects on Colombian economic growth. Grun (2008) analyses the impact of violence on household decisions and find that both guerrilla and common violence have consequences that reach beyond their immediate destructive effect.

Both at the international level and in the Colombian case, the studies have analysed the social and economic causes of violence and effects on economic growth and development using typical empirical analysis. However, the results obtained from this kind of analysis do not provide enough information that allow the analysis of the effectiveness of the control of violence and the factors affecting this effectiveness in a different context. In the available body of literature on violence, hardly any attention is paid to the effectiveness of the control of violence and its determinants. Against this background, the main goals of this study are twofold. First, we analyse the effectiveness of the control of violence in the Colombian departments ${ }^{3}$ using DEA. Second, we determine the factors that affect the effectiveness of the control of violence using a regression analysis. We carry out the analysis for the time period 1993-2007.

Measuring the effectiveness of the control of violence can play an important role in achieving improvements in the welfare of population, as the violence can have negative effects on the economic development of the countries. Developing and reporting performance information is crucial to identifying performance improvements and thus guiding decision-making. Comparative performance reporting is typically undertaken co-operatively to assist all participants to improve their performance. Moreover, Becker (1968) has demonstrated that optimal policies to combat violence are part of an optimal allocation of resources. In this context, DEA is an analytical tool that can assist in the identification of best practices in the use of resources among a group of organisations. Such identification can highlight possible improvements in effectiveness that may help public agencies to achieve their potential. Therefore, this study provides new evidence on the control of violence and the effects of structural risk and proximate risk factors in the effectiveness of their control.

\footnotetext{
${ }^{3}$ In the Colombian case, there are 32 sub-national political territories called departments.
} 
In the last few years, some researchers have analysed economic development using DEA. Raab and Habib (2007) have developed a generalised efficiency to rank developing and developed nations in terms of overall production efficiency, using linear programming to measure and rank the relative technical efficiency. Malul et al. (2009) introduce an efficiency ranking to measure the economic, environmental and social efficiency of countries. Adler et al. (2009) measure the relative socio-economic performance of developing countries. Different DEA linear programming models have been developed to assess the relative performance of the countries in terms of human development (Mahlberg and Obersteiner 2001; Despotis 2005; Somarriba and Pena 2009; Despotis et al. 2009). Ramanathan (2006) studies economic performance through DEA in countries of the Middle East and North Africa. Habibov and Fan (2009) compare and contrast the poverty reduction performance of social welfare programs in Canada. These studies have demonstrated that DEA in conjunction with traditional measures on development, and growth are an alternative and effective method to measure and rank the economic, development and social efficiency in different approaches.

Moreover, in criminology DEA has been used to evaluate the efficiency from different approaches. Hence, Butler and Johnson (1997) assessed the relative efficiency of prison operations and to set targets for improvement identifying the source of inefficiency and potential remedies. Sun (2002) measured the relative efficiency of police precincts in Taiwan showing that differences in operation and process depend mainly of resident population and location factors. Verma and Gavirneni (2006) measured policy efficiency in India found that DEA helps to generate targets of performance, identify inefficient departments, and determine adequate levels of operation and improvements in the unit of criminal justice systems. Garcia (2007) evaluated the effectiveness of the Spanish police force determined that the units with the most effective overall are characterized by the solving of crimes against the right to sexual freedom and indemnity and by the arrest of a high percentage of those guilty of other offences. These studies show the applicability of DEA in the analysis of efficiency of criminal justice. However, these researches have not evaluated the effectiveness of the control of violence and socioeconomic development, which is the aim of this study.

In Colombia, DEA models have also been applied in studies of the performance and efficiency of power distribution systems (Pombo and Taborda 2006), production costs (López et al. 2007), the analysis of ranking Colombian research groups (Restrepo and Villegas 2007) and the analysis of energy efficiency in manufacturing industries (Pardo 2009, 2010). However, DEA has not been applied to measure and rank the efficiency from an economic development and social approach being this a singular feature of this research in the Colombian context.

With this background, the contribution of this study is that it employs DEA to compare the effectiveness of the control of violence within Colombian departments by considering different variables as input and output from the mix of the department's situation. It also identifies the best-performing departments over time and defines the factors that affect these results where the studies are limited.

The rest of this paper is organised into five sections. Following the introduction, the second section describes DEA and the methodological foundation of this study. The third section provides an empirical illustration of the application of DEA to the analysis and comparison of the effectiveness of the control of violence in the Colombian departments, the justification for the adoption of DEA and the data construction. The fourth section shows the results of DEA. The fifth section applies an econometric model to investigate the 
sources of differences in the effectiveness of the control of violence in Colombian departments. The sixth section concludes the paper and provides some policy suggestions.

\section{Data Envelopment Analysis}

Data envelopment analysis (DEA) is a mathematical programming methodology that uses the Frontier approach to measure the relative efficiency or performance of decision-making units (DMUs) based on a fractional programming problem that has been converted to a linear programming problem. In DEA, a DMU is regarded as an entity transforming inputs into outputs. A DMU can be a company, a non-profit organisation, or a jurisdiction with multiple inputs and outputs (Charnes et al. 1978; Banker et al. 1984; Charnes et al. 1994).

DEA was first developed as an application of linear programming to analysis efficiency in production by Charnes et al. (1978), who used what is now called the CCR-model, based on the method of frontier analysis by Farrel (1957). Different DEA models have since been further developed; examples are a model of variable returns to scale, or the BCC model, by Banker et al. (1984), the "Malmquist" index model (CCD), developed by Caves et al. (1982), and window analysis, which assesses the performance of a DMU over time by treating it as a different entity in each time period (Charnes et al. 1985).

The basic concept and the general form of a DEA (input-oriented CCR) model can be presented as follows (Ramanathan 2003): for each DMU, we have multiple inputs and outputs, which are linearly aggregated by weights to be determined by the DEA program.The virtual inputs and outputs are formed as follows:

$$
\begin{aligned}
\text { Virtual input } & =v_{1} x_{1}+\cdots+v_{I} x_{I}=\sum_{i=1}^{I} v_{i} x_{i}, \\
\text { Virtual output }=u_{1} y_{1}+\cdots+u_{J} y_{J} & =\sum_{j=1}^{J} u_{j} y_{j},
\end{aligned}
$$

where $v_{1}$ is the weight assigned to input $x_{i}$, and $u_{i}$ is the weight assigned to output $y_{i}$ in the linear aggregation. Variables $x_{i}$ and $y_{i}$ are the actually observed inputs and outputs for determining the weights. The following model is used to maximise the ratio:

$$
\text { Efficiency }=\frac{\text { Virtual output }}{\text { Virtual input }}=\frac{\sum_{j=1}^{J} u_{j} y_{j}}{\sum_{i=1}^{I} v_{i} x_{i}} .
$$

As can be observed, this is a generalisation of the model achieved through a reduction from a "multiple-output-multiple input" situation to the situation of a single "virtual" output and a single "virtual" input. The efficiency of a DMU can be defined as the ratio of "virtual output" to "virtual input", with weights to be determined. Suppose that we are going to compare the efficiencies of $n$ DMUs and that the DMUs under analysis have $x_{i m}$ inputs and $y_{j m}$ outputs. In particular, it takes any mth DMU that uses $x_{i m}$ inputs to produce $y_{j m}$ outputs and maximise its efficiency as the reference DMU. To measure the efficiency of this process by a DMU, a fractional mathematical programming model, denoted as Eq. (1) below, is proposed. The objective function of the model maximises the ratio of weighted outputs to weighted inputs for the DMU under evaluation, subject to the condition that the similar ratios for all DMUs be less than or equal to one (Ramanathan 2003). The formula is as follows: 
$\operatorname{Max} E_{m}=\frac{\sum_{j=1}^{J} u_{j m} y_{j m}}{\sum_{i=1}^{I} v_{i m} x_{i m}}$,

subject to

$$
\begin{aligned}
& 0 \leq \frac{\sum_{j=1}^{J} u_{j m} y_{j m}}{\sum_{i=1}^{I} v_{i m} x_{i m}} \leq 1 ; \quad n=1,2, \ldots, N, \\
& v_{j m}, u_{i m} \geq 0 ; \quad i=1,2, \ldots, I ; \quad j=1,2, \ldots, J,
\end{aligned}
$$

where $E_{m}$ is the efficiency of the mth DMU, $x_{i m}$ and $y_{j m}$ are the input and output of mth DMU, respectively, $v_{i m}$ and $u_{j m}$ are the weights assigned to input $x_{i m}$ and output $y_{j m}$, respectively, and $x_{i n}$ and $y_{j n}$ are the ith input and jth output of nth DMU, $n=1,2, \ldots, \mathrm{N}$, respectively. The weights for each input and output are selected such that the associated DMU obtains a score that places it in the best possible light. Each DMU has its own unique set of weights restricted from 0 to 1 , determined by linear programming.

The mathematical formula analysed above is fractional in form and difficult to solve. However, it can be solved easily by normalising either the numerator (maximising the outputs) or denominator (minimising the inputs) of the fractional form. An output maximisation model is expressed as follows:

$$
\operatorname{Max} z=\sum_{j=1}^{J} u_{j m} y_{j m},
$$

subject to

$$
\begin{aligned}
& \sum_{i=1}^{I} v_{i m} x_{i m}=1, \\
& \sum_{j=1}^{J} u_{j m} y_{j n}-\sum_{i=1}^{I} v_{i m} x_{i n} \leq 0, \\
& v_{j m}, u_{i m} \geq 0 ; \quad i=1,2, \ldots, I ; \quad j=1,2, \ldots, J,
\end{aligned}
$$

where $x_{i m}, y_{j m}, v_{i m}, u_{j m}, x_{i n}$ and $y_{j n}$ are indicated as above. This is an ordinary linear programming problem. Elements for the transformation from problem in (1) to the linear programming solution in (2) can be found in studies by Charnes et al. (1978) and Cooper et al. (2000).

In DEA, a DMU or several DMUs for which the efficiency is maximised is called the reference set (Charnes et al. 1994; Cooper et al. 2000). DEA identifies the reference set that consists of relatively efficient DMUs that are most similar to each DMU being evaluated. The performance of evaluated DMUs is measured by their divergence from the reference set. Consequently, a unique reference set is developed for each DMU; the reference set for an inefficient DMU may differ from unit to unit. The DMUs included in the reference set are the benchmarks for the evaluated DMU. By evaluating the performance of each DMU against the benchmarks, DEA identifies sources and computes the amounts of inefficiencies in each input and each output for each DMU.

Following this, sources and amounts of inefficiencies are translated into the amounts of input and/or output that should be changed to make the DMU efficient relative to the benchmarks. The proposed changes in input and output set targets for future improvements for each DMU. 


\subsection{Application Considerations of DEA}

There are several important issues faced in DEA application. First, DEA models require that both of the input and output variables be positive. If a variable is not positive, the variable should be transformed by an affine displacement, which does not alter the identification of DMUs in the efficient frontier, as shown in the study by Ali and Seiford (1990). In this paper, all selected inputs and outputs are positive. Second, all DMUs under analysis should be homogeneous entities that have the same inputs and produce the same outputs. Finally, as in other methods based on statistics, DEA also has the issue of stability in the form of degrees of freedom. In DEA, the degrees of freedom increase with the number of DMUs and decrease with the number of inputs and outputs. A general rule of thumb is as follows:

$$
n \geq \max \{m \times s, 3(m+s)\},
$$

where $n$ is the number of DMUs, $m$ is the number of inputs and $s$ is the number of outputs (Cooper et al. 2000). Therefore, the minimum number of DMUs is either the product of the number of inputs and the number of outputs or three times that of the sum of the number of inputs and outputs, whichever is bigger. In this study, we have 4 inputs (desirable attributes) and 3 outputs (undesirable attributes), and we need at least 21 DMUs to meet the required degrees of freedom. In this analysis, we have divided the departments in three groups with the aim of obtaining comparable decision-making units (DMUs). The groups of departments are the following: departments with a high level of violence, departments with a moderate level of violence, and departments with a low level of violence. Therefore, for every group, there are only a maximum of 11 departments in Colombia, implying that we have at less 21 DMUs. However, this can be solved in this analysis by the application of a window analysis. In window analysis, for each evaluation, we have 33 DMUs for Departments with a high level of violence and Departments with a middle level of violence, and we have 30 DMUs for Departments with a low level of violence.

In DEA, it is necessary to consider the construction of the production frontier, which is the subset of all feasible techniques that attain the highest effectiveness of the control of violence for the particular features they correspond to. In case of panel data literature defines three different kinds of frontiers (Contemporaneous, Inter-temporal and Sequential). ${ }^{4}$ In this study, we used the inter-temporal frontier, where the production possibility set is defined as $S^{\prime}=\left\{(x, y): x \geq \sum_{i=1}^{n} \sum_{t=1}^{t} \lambda_{i}^{t} x_{i}^{t} ; y \leq \sum_{i=1}^{n} \sum_{t=1}^{t} y_{i}^{t} y_{i}^{t}\right\}$, when there are $n$ units observed over $T$ periods of time at which the DMU is being evaluated. This frontier is selected because it captures overall efficiency change over time, it assumes technical progress or regress taking into account that the measures of efficiency in each year can be compared and can be taken as indicators of advance or decline in performance, and it leads to greater degrees of freedom and therefore, more variation in the measured efficiencies. Moreover, in DEA, the stochastic frontier includes the possibility of measurement errors in the input and output variables as well as indeterminacy in the estimated frontiers due to limited samples in comparison with deterministic frontier (Kenneth et al. 1994; Ray 2004).

\footnotetext{
${ }^{4}$ DEA analysis defines three types of frontiers with panel data: (a) the contemporaneous builds from only the cross-section data from a given period, (b) the sequential considers all current and past observations as feasible, and (c) the inter-temporal uses observations from all the periods in the sample (Tulkens and Eeckaut 1995).
} 


\subsection{Window Analysis}

Window analysis is a moving-average model that comprises of a series analysis with timedependent DMUs as described in Charnes et al. (1985) and in Bowlin (1987). In window analysis, the same department in different time periods is treated as different DMUs. As a result, the performance of a department is not only compared with that of other departments at the same time but also compared with itself at different time periods. For example, this analysis selects a 3 year window for the study over a 15 year period from 1993 to 2007 for 32 Colombian departments divided as departments with a high-, middle-, or low level of violence. In the first window, data of year 1, year 2 and year 3 are analysed; the window covers 1993-1995 and so on until the last window, year 13, year 14 and year 15 are included. Therefore, for each window in analysis, we have 30 or 33 DMUs. There are two major benefits of using window analysis. First, it increases the number of DMUs and allows for more input and output variables to be taken into account in a given number of DMUs. By increasing the number of variables in DEA, window analysis overcomes the constraints of degrees of freedom. Second, it can be used to test the stability of performance of each department over a period of time. In that way, window analysis may reveal more meaningful implications regarding the changes in the performance of analysed DMUs, by examining their efficiency in dynamic settings.

\section{Empirical Illustration: The Effectiveness of the Control of Violence in Colombia}

In this section, DEA is applied to evaluate and compare the effectiveness of the control of violence in Colombian departments. When assessing the performance of Colombian departments, DEA combines the performance of Colombian departments in terms of several desirable (inputs) and undesirable (outputs) attributes into a single scalar measure, called the efficiency score. Departments that register unit efficiency scores are considered efficient in that they have the highest values of desirable attributes and the lowest values of undesirable attributes. Departments with efficiency scores less than 1 may be considered to operate sub-optimally for a given set of attributes. ${ }^{5}$

As noted above, DEA uses two sets of variables: input (desirable attributes) and output (undesirable attribute). For the purpose of this study, we treat each Colombian department as a separate DMU with its own input and output values. Each DMU has desirable attributes-denominated input variables and undesirable attributes-denominated output variables. Of the seven attributes, homicides, kidnapping and robberies represent undesirable attributes (outputs) whereas confiscated drugs, budget execution, captures and number of policeman represent desirable attributes (inputs). This model assumes that the score increases when a department achievement improves its desirable attributes (inputs), and the score decreases when a department increases its undesirable attributes (outputs). The choice of attributes for this study is influenced by issues of data consistency, reliability and affordability.

In this study, when computing efficiency scores using DEA, we assume constant returns to scale (CRS) with output-oriented where the model minimise the undesirable attributes (outputs) whereas maximise the desirable attributes (inputs). Before detailing our study, we

\footnotetext{
5 This concept follows that used by Ramanathan (2006) to evaluate the comparative performance of countries of the Middle East and North Africa.
} 
show the justification of using DEA. The following are selected important features and advantages of using DEA for a comparative analysis of Colombian departments.

\subsection{Justification for Adoption of DEA}

We can return to three major reasons for employing DEA for the analysis of the effectiveness of the control of violence across Colombian departments. First, each department uses multiple inputs (desirable attributes) and multiple outputs (undesirable attributes). Therefore, the analyst faces the challenge of assessing the system with multiple inputs and multiple outputs. As a quantitative technique, DEA is specially designed to determine efficiency using multiple inputs and multiple outputs. DEA allows assessing the aggregated effectiveness of the control of violence, as it produces a single composite measure to rank departments by their relative efficiency in the effectiveness of the control of violence. A single ranking such as this can be easily understood by policy makers, social administrators, media and the general population.

Second, DEA reveals best-practice performance, which are different from the average performance levels produced by a regression analysis. Regression analysis generates a central tendency line (based on the least-squares principle) that identifies the average performance of departments. Afterwards, it is possible to determine the performance of a department as "above average" if a unit is above the line or as "inferior" if a unit is below the line. The degrees of the excellence or inferiority of the performance is estimated by amounts of deviation from the line (Habibov and Fan 2009). On the contrary, DEA identifies the best department to set benchmarks and then measures the performance of other departments by their deviation from the benchmarks. As a result, each department is compared with the best possible performance among the peers rather than with the average as in the case of regression analysis. Furthermore, because DEA compares each department with benchmarks, it is possible to compute to what extent specific inputs and outputs should be changed to make the department relatively efficient. By showing the amounts and sources of inefficiencies, DEA provides a foundation for future corrective actions. This feature of DEA is different from other statistical approaches, such as regression analysis, which is not able to identify sources or amounts of inefficiencies (Bowlin 1998).

Finally, when DEA is extended to evaluate social performances, terms like "inputs" and "outputs" are largely generic (to conform to DEA usages), as can be seen in earlier DEA applications (Golany and Thore 1997; Raab et al. 2000). For example, the current study uses "budget execution" as an input and "homicides" as an output. However, they cannot be considered an input and output, respectively, in the traditional sense of DEA. That is, "budget execution" cannot be said to produce "homicides". In this sense, performance levels in terms of undesirable attributes are considered outputs, and performance levels in terms of desirable attributes are considered inputs. Such generic usage is also true of DMUs. In a traditional DEA context, DMUs are entities that convert inputs into outputs. Here however, the term denotes only the entity (a department) under consideration. Nevertheless, DEA can be used to compare the performance of different departments by the scalar efficiency score. The score increases when department achievements increase in terms of desirable attributes and decreases when achievements increase in terms of undesirable attributes (Ramanathan 2006).

Taken together, the evidence presented above suggests that DEA can be adopted for the comparison of the effectiveness of the control of violence across Colombian departments. The results from DEA model specified in this study are robustness and suitable taking account the analysis of Smith (1997) on accurate estimates of efficiency using DEA. 


\subsection{Data Construction}

DEA evaluates the relative efficiency of a set of comparable entities with multiple inputs and outputs. In this study, Colombian departments are divided among departments with a high level of violence, a moderate level of violence and a low level of violence (see Fig. 1) using k-means clustering (MacQueen 1967), where, given a set of observations $\left(z_{1}, z_{2}, \ldots\right.$, $z_{\mathrm{n}}$ ), each observation is a d-dimensional real vector, then $k$-means clustering aims to partition the n observations into k sets $(k<n) S=\left\{S_{1}, S_{2}, \ldots, S_{k}\right\}$ so as to minimise the within-cluster sum of squares (see Eq. 3). K-means clustering analysis uses the variables homicide rates, population and gross domestic product for each department.

$$
\arg \min s \sum_{i=1}^{k} \sum_{z_{j} \in S_{i}}\left\|z_{j}-\bar{x}_{i}\right\|^{2}
$$

where $\bar{x}_{i}$ is the mean of $\mathrm{S}_{\mathrm{i}}$.

The data of Colombian departments come from the National Police of Colombia, the Colombian defence ministry, the DNP (National Planning Department), and the Colombian finance and public credit ministry. Input variables as desirable outputs are measured as kilograms of confiscated drugs by department, budget execution as public expenditure executed by year in Colombian departments, measured as pesos in the year 2000, the number of captures or apprehensions by department, and the number of policeman by department. Output variables as undesirable attributes are measured as the number of homicides, kidnapping and robberies by department.

\section{Comparing the Effectiveness of the Control of Violence in Colombian Departments Using DEA}

First of all, we examine the traditional measure of violence by computing the homicide rates per 100,000 in the population. The average homicide rates of Colombian departments during this period were 49.78 homicides per 100,000 in the population. The average homicide rates increased over 2001-2002 and declined thereafter as a consequence of the fractured institutions generated during and after peace negotiations made by the Pastrana government, where the end stage of the negotiation process was particularly violent and thus increased the homicide rates. The departments with the highest homicide rates are Arauca and Guaviare (more than 100 homicides per 100,000 in the population), whereas Amazonas and San Andres have the lowest homicide rates (less than 15 homicides per 100,000 in the population).

The resulting efficiency scores of Colombian departments regarding the effectiveness of the control of violence are indicated in Table 1 and Fig. 2. Note that the listed efficiencies should be viewed relative to the best-performing department (departments). The departments were ranked taking into account the criterion based on the frequency with which an effective unit appears as a referent for ineffective ones. Two columns added on the right of the table provide results for the stability of each departments DEA ranking. These two columns show the mean efficiency rating and variance over the evaluations. These columns exhibit highly stable results for efficiency scores; several departments have very low variance. The results of our analysis show that the effectiveness of the control of violence is on average $73 \%$ for departments with a high level of violence, $80 \%$ for departments with a middle level of violence and $72 \%$ for departments with a low level of violence, indicating that departments 


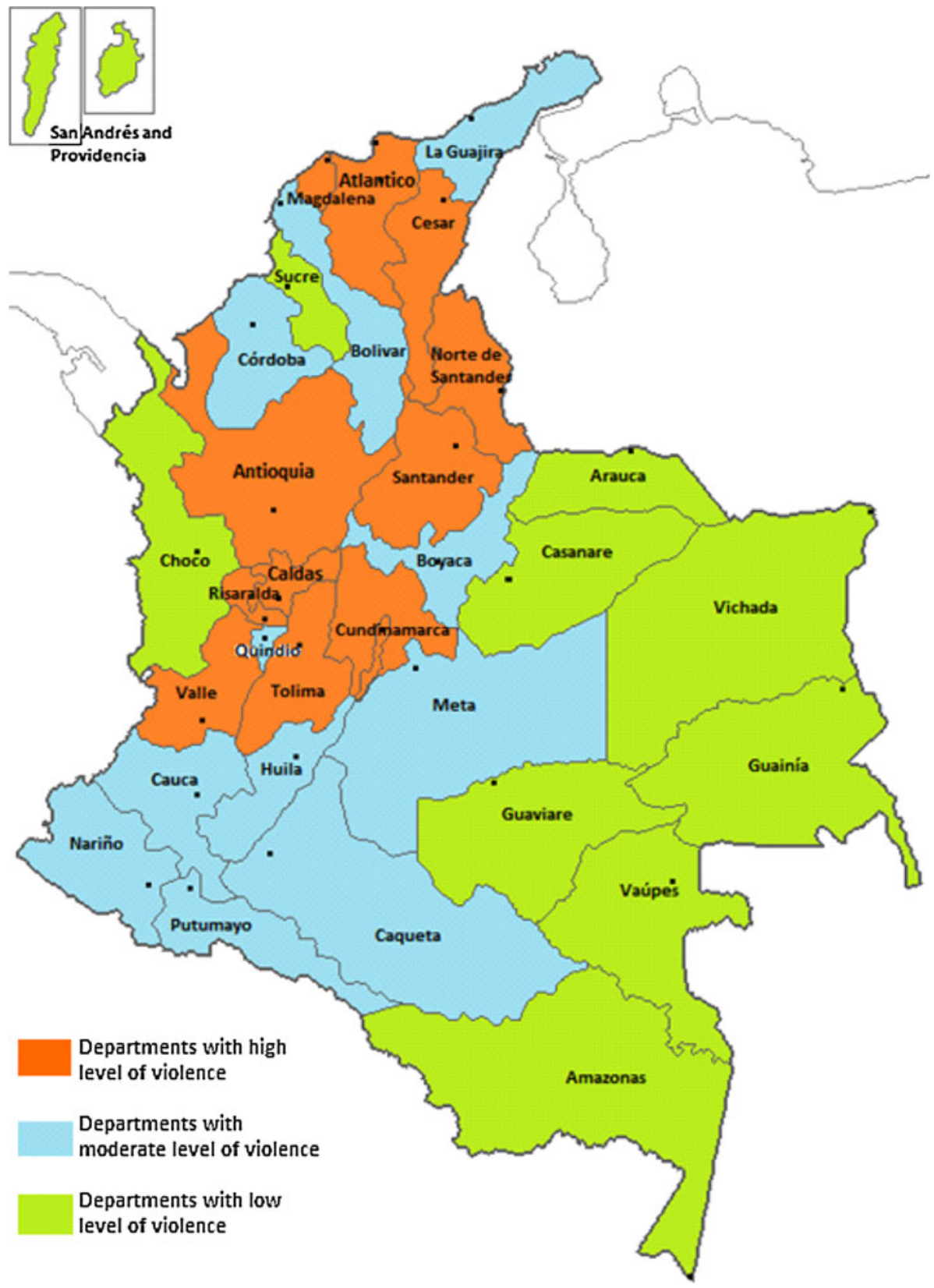

Fig. 1 Distribution of violence in Colombia by departments

with a middle level of violence show the best performance, while departments with a low level of violence show the worst performance in the control of violence.

In the departments with a high level of violence, the effectiveness score ranges from 0.26 to 1.00 . The majority of departments show improvement in their effectiveness scores except for Atlántico, Caldas, Risaralda and Tolima. The departments with the best 


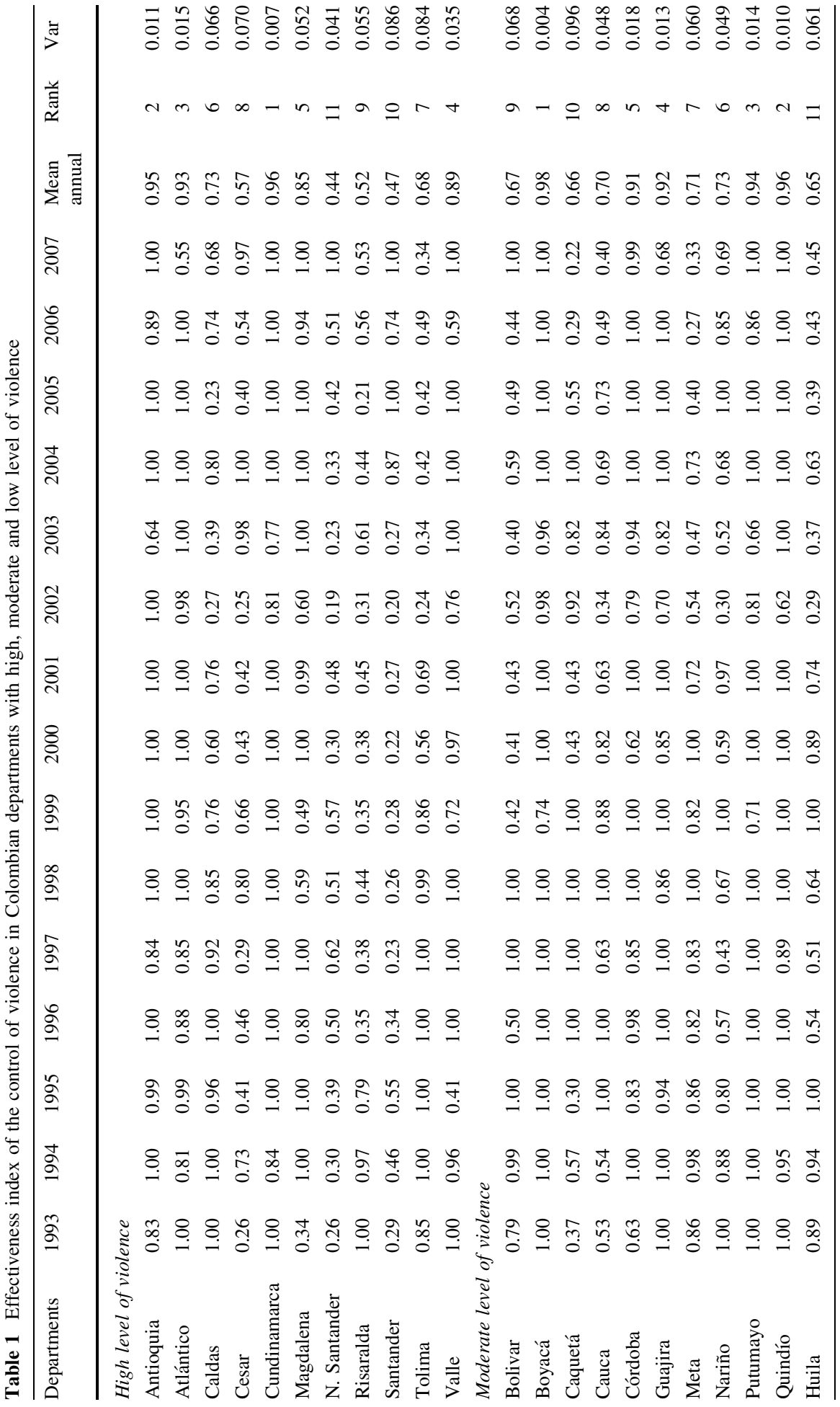




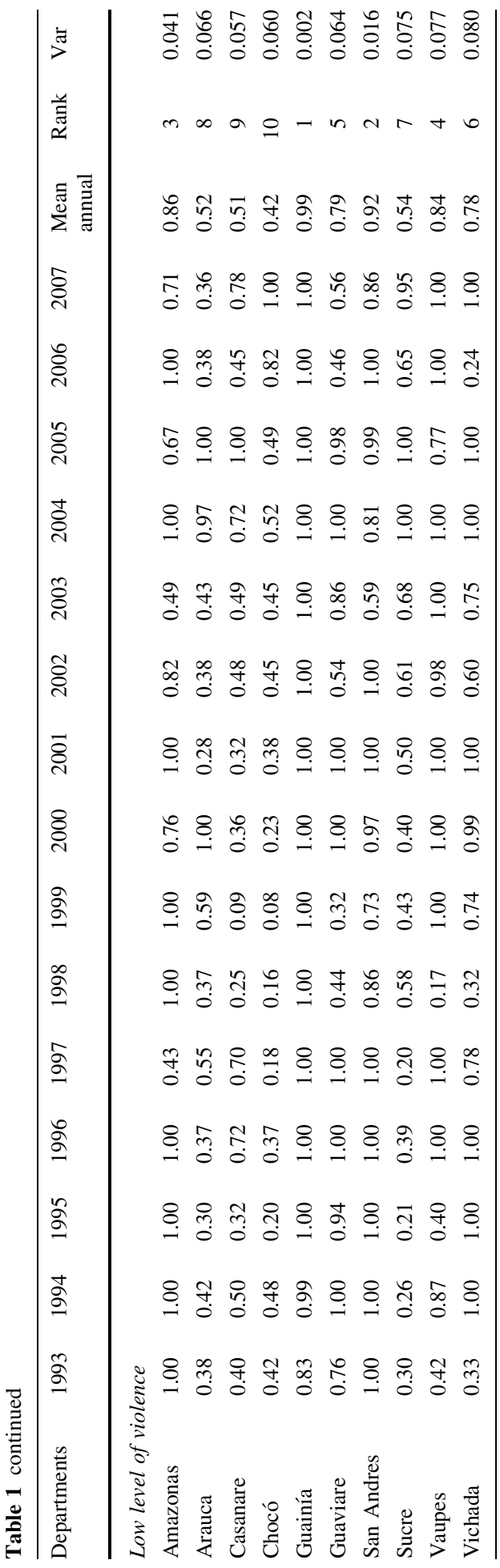



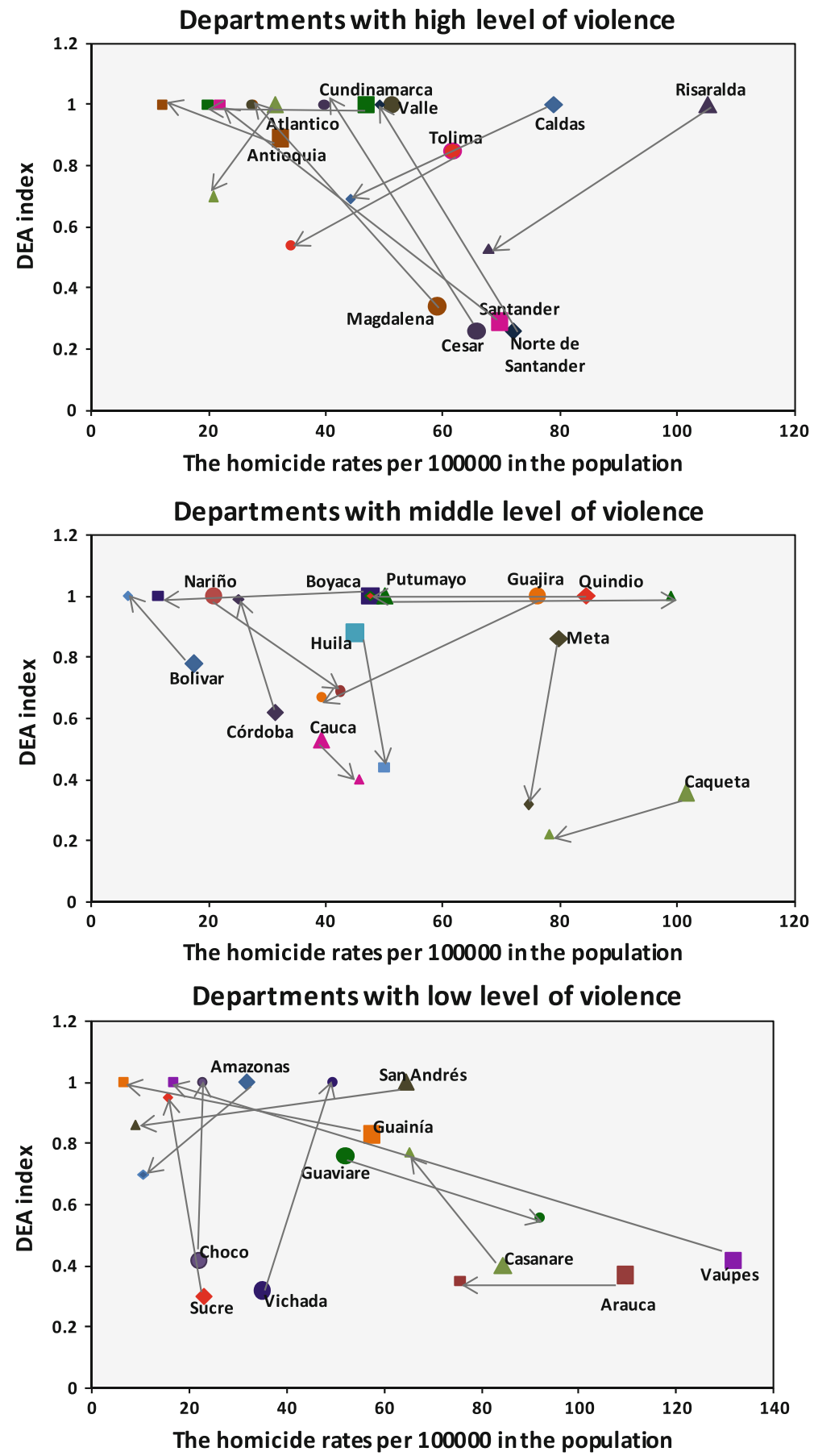

Fig. 2 Results of DEA for Colombian departments. Note: The larger symbols represent values for 1993 whereas the small represent values for 2007. The arrows indicate, in a schematic way, the change in each department 
performance are Cundinamarca, Antioquia and Valle, while North of Santander, Santander and Risaralda show the worst performance during the sample period.

In the departments with a moderate level of violence, the effectiveness score ranges from 0.22 to 1.00 . The majority of departments show an improvement in their effectiveness scores except for Bolivar, Cordoba, Guajira, Meta, Nariño and Huila. The departments with the best performance are Boyacá, Quindío and Putumayo, while Bolivar, Caquetá and Huila show the worst performance during the sample period.

In the departments with a low level of violence, the effectiveness score ranges from 0.08 to 1.00. The majority of departments show an improvement in their effectiveness scores except for Amazonas, and San Andres. The departments with the best performance are Guainía and San Andres, while Chocó, Casanare, and Arauca show the worst performance during the sample period.

\section{Explaining Inter-department Variations in Effectiveness of the Control of Violence}

The results show variation across Colombian departments, indicating that each situation of violence features its particular unique mix of drivers, dynamics and effects. Any external intervention must be sensitive to the context in which armed violence occurs. Despite their unique characteristics, however, most situations of violence also share a number of common underlying structural and proximate risk factors.

Structural risk factors include social, political and economic inequalities/exclusion; systemic unemployment and underemployment; rising perceptions of economic deprivation or grievances; rising expectations in the face of limited or non-existent opportunities; weak or problematic governance (including impunity in the judicial system and an ineffective criminal justice system, public security failure, corruption, penetration by organised crime and illicit markets, insufficient investments in social policies and programming, under-governed spaces and other deficits that compromise effective, impartial governance); resource scarcity and competition; rapid and unregulated urbanisation and limited education and employment opportunities (GDS 2008). In this study, to analysis these factors, we include the following variables: political violence, collective homicide, collective homicide victims, gross domestic product, education, unemployment rate, unsatisfied basic needs, GINI, and employments per industry.

Proximate risk factors include sharp economic shocks; natural (and human-induced) disasters such as drought; easy access to alcohol, narcotics, and small arms; and fresh exposure to past violence (WHO 2002). In this factor, we include the following variables: displaced population and hectares cultivated with coca.

To explain the observed variation of the effectiveness of the control of violence and structural and proximate risk factors across Colombian departments during our sample period, we employ regression analysis. The measures of effectiveness estimated (SE) in this paper are used as dependent variables in the various regression models and include different structural and proximate risk factors. The multiple regression for effectiveness of the control of violence is estimated using the Maximum likelihood estimation (MLE), ${ }^{6}$

\footnotetext{
${ }^{6}$ This study uses MLE because it is generally the most efficient estimation procedure in the class of estimators that use information on the distribution of the endogenous variables given the exogenous variables (Wooldridge 2001). Moreover, the results of Hausman Test indicated that random effect is the best model in the case of our empirical analysis.
} 
which is the appropriate method to use in two-stage procedures where DEA is the stage 1 and MLE is the stage 2 which produces consistent estimators (Banker and Natarajan 2008; McDonald 2009). The structural equation in the MLE is:

$$
\begin{aligned}
l_{i}= & \frac{1}{2}\left(\frac{1}{\sigma_{e}^{2}}\left[\sum_{t=1}^{T_{i}}\left(y_{i t}-x_{i t} \beta\right)^{2}-\frac{\sigma_{u}^{2}}{T_{i} \sigma_{u}^{2}+\sigma_{e}^{2}}\left\{\sum_{t=1}^{T_{i}}\left(y_{i t}-x_{i t} \beta\right)\right\}^{2}\right]\right. \\
& \left.+\ln \left(T_{i} \frac{\sigma_{u}^{2}}{\sigma_{e}^{2}}+1\right)+T_{i} \ln 2 \pi \sigma_{e}^{2}\right)
\end{aligned}
$$

The models used in this study are as follows:

The control of violence in Colombian Departments with high level of violence

$$
\begin{aligned}
\Delta S E_{i t}= & \gamma_{0}+\gamma_{1} * P V_{i t}+\gamma_{2} * G D P_{i t}+\gamma_{3} * U E_{i t}+\gamma_{4} * E D U_{i t}+\gamma_{5} * U B N_{i t} \\
& +\gamma_{6} * H C C_{i t}+\gamma_{7} * D P_{i t}+\gamma_{8} * G I N I_{i t}
\end{aligned}
$$

The control of violence in Departments with middle level of violence

$$
\begin{aligned}
\Delta S E_{i t}= & \gamma_{0}+\gamma_{1} * E D U_{i t}+\gamma_{2} * U B N_{i t}+\gamma_{3} * P V_{i t}+\gamma_{4} * G I N I_{i t}+\gamma_{5} * H C C_{i t}+\gamma_{6} * E I_{i t} \\
& +\gamma_{7} * U E_{i t}+\gamma_{8} * D P_{i t}
\end{aligned}
$$

The control of violence in Departments with low level of violence

$$
\begin{aligned}
\Delta S E_{i t}= & \gamma_{0}+\gamma_{1} * G D P_{i t}+\gamma_{2} * E D U_{i t}+\gamma_{3} * U E_{i t}+\gamma_{4} * U B N_{i t}+\gamma_{5} * C H_{i t} \\
& +\gamma_{6} * H C C_{i t}+\gamma_{7} * E I_{i t}+\gamma_{8} * D P_{i t}
\end{aligned}
$$

The control of violence in whole Colombian Departments

$$
\begin{aligned}
\Delta S E_{i t}= & \gamma_{0}+\gamma_{1} * P V_{i t}+\gamma_{2} * G D P_{i t}+\gamma_{3} * E D U_{i t}+\gamma_{4} * U E_{i t}+\gamma_{5} * U B N_{i t} \\
& +\gamma_{6} * H C C_{i t}+\gamma_{7} * D P_{i t}+\gamma_{8} * G I N I_{i t}
\end{aligned}
$$

Note that $S E_{i t}$ is the DEA score measuring the effectiveness of the control of violence in the period $t$ for the department $i ; P V_{i t}$ is the political violence, measured as the number of political homicides in the period $t$ for the department $i$; GDP $P_{i t}$ is the aggregate-level production per capita by department; $U E_{i t}$ is the unemployment rate by department; $E D U_{i t}$ is coverage education by department; $U B N_{i t}$ is the level of unsatisfied basic needs by department; $H C C_{i t}$ is the hectares cultivated with coca by department $D P_{i t}$ is the displaced population by department; $G I N_{i t}$ is the coefficient of the Gini index in period $t$ for department; $E I_{i t}$ is the number of employments by industry by department; and $\mathrm{CH}_{i t}$ is the collective homicides by department.

The results from the MLE models are reported in Tables 2, 3, 4 and 5. As expected, political violence has a negative influence on the effectiveness of the control of violence and is significant, indicating that higher politic violence lower the effectiveness of the control of violence. This result concurs with Adler et al. (2009) and Collier (2007), which show that political violence leads to the destruction of human lives and economic assets and stops the accumulation of capital and wealth. These studies provide evidence that insecurity and instability in conflict and post-conflict countries create long-term developmental difficulties.

The GDP variable has a positive and significant coefficient, implying that departments with higher GDP may experience higher effectiveness in the control of violence, which concurs with Holmes et al. (2002), indicating that in Colombia, guerrilla and paramilitary 
Table 2 Results of MLE regressions for explaining effectiveness of the control of violence in Colombian Departments with high level of violence

\begin{tabular}{|c|c|c|c|c|c|}
\hline Parameter & [1] & {$[2]$} & [3] & [4] & {$[5]$} \\
\hline Constant & $\begin{array}{l}1.509 * * * \\
(0.168)\end{array}$ & $\begin{array}{l}1.791 * * * \\
(0.583)\end{array}$ & $\begin{array}{l}1.685 * * * \\
(0.562)\end{array}$ & $\begin{array}{l}1.936 * * * \\
(0.653)\end{array}$ & $\begin{array}{l}1.950 * * * \\
(0.669)\end{array}$ \\
\hline Political violence & $\begin{array}{c}-0.029 * \\
(0.015)\end{array}$ & $\begin{array}{c}-0.028 * \\
(0.015)\end{array}$ & $\begin{array}{r}-0.028 * \\
(0.015)\end{array}$ & $\begin{array}{r}-0.019 \\
(0.015)\end{array}$ & $\begin{array}{r}-0.018 \\
(0.015)\end{array}$ \\
\hline GDP & $\begin{array}{l}3.18 \mathrm{e}-08 * * * \\
(9.68 \mathrm{e}-09)\end{array}$ & $\begin{array}{l}3.04 \mathrm{e}-08 * * * \\
(9.46 \mathrm{e}-09)\end{array}$ & $\begin{array}{l}3.29 \mathrm{e}-08 * * * \\
(9.20 \mathrm{e}-09)\end{array}$ & $\begin{array}{l}3.93 \mathrm{e}-08 * * * \\
(1.11 \mathrm{e}-08)\end{array}$ & $\begin{array}{l}4.01 \mathrm{e}-08 * * * \\
(1.35 \mathrm{e}-08)\end{array}$ \\
\hline Unemployment rate & $\begin{array}{l}-0.268 * * * \\
(0.061)\end{array}$ & $\begin{array}{l}-0.286 * * * \\
(0.068)\end{array}$ & $\begin{array}{l}-0.283 * * * \\
(0.068)\end{array}$ & $\begin{array}{l}-0.210 * * * \\
(0.071)\end{array}$ & $\begin{array}{c}-0.210 * * * \\
(0.071)\end{array}$ \\
\hline Education & $\begin{array}{l}0.201 * * * \\
(0.073)\end{array}$ & $\begin{array}{l}0.210^{* * * *} \\
(0.079)\end{array}$ & $\begin{array}{l}0.224 * * * \\
(0.076)\end{array}$ & $\begin{array}{l}0.237 * * * \\
(0.077)\end{array}$ & $\begin{array}{l}0.233 * * * \\
(0.084)\end{array}$ \\
\hline $\begin{array}{l}\text { Unsatisfied basic } \\
\text { needs }\end{array}$ & & $\begin{array}{r}-0.062 \\
(0.130)\end{array}$ & $\begin{array}{r}-0.034 \\
(0.125)\end{array}$ & $\begin{array}{r}-0.0002 \\
(0.148)\end{array}$ & $\begin{array}{r}-0.012 \\
(0.186)\end{array}$ \\
\hline $\begin{array}{l}\text { Hectares cultivated } \\
\text { with coca }\end{array}$ & & & $\begin{array}{r}-0.00001 \\
(0.00001)\end{array}$ & $\begin{array}{r}-6.38 \mathrm{e}-06 \\
(0.00001)\end{array}$ & $\begin{array}{r}-6.30 \mathrm{e}-06 \\
(0.00001)\end{array}$ \\
\hline $\begin{array}{l}\text { Displaced } \\
\text { population }\end{array}$ & & & & $\begin{array}{c}-0.068 * * * \\
(0.025)\end{array}$ & $\begin{array}{c}-0.069 * * \\
(0.027)\end{array}$ \\
\hline GINI & & & & & $\begin{array}{r}-0.095 \\
(0.895)\end{array}$ \\
\hline No. obs & 158 & 158 & 158 & 158 & 158 \\
\hline
\end{tabular}

Notes: Figures in the parentheses are standard error

* Significant at the $10 \%$ level, ** Significant at the 5\% level and *** Significant at the $1 \%$ level

Table 3 Results of MLE regressions for explaining effectiveness of the control of violence in Colombian Departments with middle level of violence

\begin{tabular}{|c|c|c|c|c|c|}
\hline Parameter & {$[1]$} & {$[2]$} & {$[3]$} & [4] & {$[5]$} \\
\hline Constant & $\begin{array}{l}0.714 * * * \\
(0.159)\end{array}$ & $\begin{array}{l}0.701 * * * \\
(0.165)\end{array}$ & $\begin{array}{l}0.850 * * * \\
(0.225)\end{array}$ & $\begin{array}{l}0.844 * * * \\
(0.189)\end{array}$ & $\begin{array}{l}0.821 * * * \\
(0.191)\end{array}$ \\
\hline Education & $\begin{array}{c}0.004 \\
(0.005)\end{array}$ & $\begin{array}{c}0.004 \\
(0.005)\end{array}$ & $\begin{array}{c}0.006 \\
(0.005)\end{array}$ & $\begin{array}{c}0.056 \\
(0.057)\end{array}$ & $\begin{array}{c}0.051 \\
(0.057)\end{array}$ \\
\hline Unsatisfied basic needs & $\begin{array}{r}-0.0003 \\
(0.001)\end{array}$ & $\begin{array}{c}-0.0002 \\
(0.001)\end{array}$ & $\begin{array}{r}-0.001 \\
(0.002)\end{array}$ & $\begin{array}{r}-0.002 \\
(0.002)\end{array}$ & $\begin{array}{r}-0.001 \\
(0.002)\end{array}$ \\
\hline Political violence & $\begin{array}{c}-0.0009 * * * \\
(0.0003)\end{array}$ & $\begin{array}{l}-0.0008 * * * \\
(0.0003)\end{array}$ & $\begin{array}{c}-0.0009 * * * \\
(0.0003)\end{array}$ & & \\
\hline GINI & $\begin{array}{r}-0.231 \\
(0.186)\end{array}$ & $\begin{array}{r}-0.247 \\
(0.194)\end{array}$ & $\begin{array}{r}-0.062 \\
(0.242)\end{array}$ & & \\
\hline $\begin{array}{l}\text { Hectares cultivated } \\
\text { with coca }\end{array}$ & & $\begin{array}{r}-8.65 \mathrm{e}-07 \\
(3.23 \mathrm{e}-06)\end{array}$ & $\begin{array}{r}-5.60 \mathrm{e}-06 \\
(4.40 \mathrm{e}-06)\end{array}$ & & \\
\hline $\begin{array}{l}\text { Employments per } \\
\text { industry }\end{array}$ & & & $\begin{array}{c}0.0005 \\
(0.0007)\end{array}$ & $\begin{array}{l}0.0005 \\
(0.001)\end{array}$ & $\begin{array}{c}0.0004 \\
(0.001)\end{array}$ \\
\hline Unemployment rate & & & & $\begin{array}{r}-0.001 \\
(0.006)\end{array}$ & $\begin{array}{c}-0.0002 \\
(0.006)\end{array}$ \\
\hline Displaced population & & & & & $\begin{array}{r}-3.53 \mathrm{e}-06 \\
(3.27 \mathrm{e}-06)\end{array}$ \\
\hline No. obs & 165 & 165 & 150 & 126 & 126 \\
\hline
\end{tabular}

Notes: Figures in the parentheses are standard error

* Significant at the $10 \%$ level, ** Significant at the $5 \%$ level and *** Significant at the $1 \%$ level 
Table 4 Results of MLE regressions for explaining effectiveness of the control of violence in Colombian Departments with low level of violence

\begin{tabular}{|c|c|c|c|c|c|}
\hline Parameter & {$[1]$} & [2] & {$[3]$} & [4] & {$[5]$} \\
\hline Constant & $\begin{array}{l}0.862 * * * \\
(0.157)\end{array}$ & $\begin{array}{l}0.862 * * * \\
(0.157)\end{array}$ & $\begin{array}{l}0.860 * * * \\
(0.160)\end{array}$ & $\begin{array}{l}0.797 * * * \\
(0.187)\end{array}$ & $\begin{array}{l}0.842 * * * \\
(0.192)\end{array}$ \\
\hline GDP & $\begin{array}{l}1.74 \mathrm{e}-08 * * \\
(8.09 \mathrm{e}-09)\end{array}$ & $\begin{array}{l}1.83 \mathrm{e}-08 * * \\
(8.75 \mathrm{e}-09)\end{array}$ & $\begin{array}{l}1.83 \mathrm{e}-08 * * \\
(8.75 \mathrm{e}-09)\end{array}$ & $\begin{array}{c}1.62 \mathrm{e}-08 * \\
(9.41 \mathrm{e}-09)\end{array}$ & $\begin{array}{r}1.58 \mathrm{e}-08 * \\
(9.49 \mathrm{e}-09)\end{array}$ \\
\hline Education & $\begin{array}{c}0.052 \\
(0.055)\end{array}$ & $\begin{array}{c}0.050 \\
(0.055)\end{array}$ & $\begin{array}{c}0.050 \\
(0.056)\end{array}$ & $\begin{array}{c}0.052 \\
(0.056)\end{array}$ & $\begin{array}{c}0.048 \\
(0.057)\end{array}$ \\
\hline Unemployment rate & $\begin{array}{c}-0.014 * * \\
(0.006)\end{array}$ & $\begin{array}{c}-0.014 * * \\
(0.006)\end{array}$ & $\begin{array}{c}-0.013 * * \\
(0.006)\end{array}$ & $\begin{array}{r}-0.012 * \\
(0.007)\end{array}$ & $\begin{array}{r}-0.012 * \\
(0.007)\end{array}$ \\
\hline $\begin{array}{l}\text { Unsatisfied basic } \\
\text { needs }\end{array}$ & $\begin{array}{r}-0.001 \\
(0.001)\end{array}$ & $\begin{array}{r}-0.001 \\
(0.001)\end{array}$ & $\begin{array}{r}-0.001 \\
(0.001)\end{array}$ & $\begin{array}{r}-0.0006 \\
(0.001)\end{array}$ & $\begin{array}{r}-0.0007 \\
(0.001)\end{array}$ \\
\hline $\begin{array}{l}\text { Collective } \\
\text { homicide }\end{array}$ & & $\begin{array}{r}-0.001 \\
(0.006)\end{array}$ & $\begin{array}{r}-0.001 \\
(0.006)\end{array}$ & $\begin{array}{r}-0.0007 \\
(0.006)\end{array}$ & $\begin{array}{r}-0.001 \\
(0.006)\end{array}$ \\
\hline $\begin{array}{l}\text { Hectares cultivated } \\
\text { with coca }\end{array}$ & & & $\begin{array}{r}-4.78 \mathrm{e}-07 \\
(7.08 \mathrm{e}-06)\end{array}$ & $\begin{array}{r}-6.26 \mathrm{e}-07 \\
(7.14 \mathrm{e}-06)\end{array}$ & $\begin{array}{r}-1.44 \mathrm{e}-06 \\
(7.23 \mathrm{e}-06)\end{array}$ \\
\hline $\begin{array}{l}\text { Employment per } \\
\text { industry }\end{array}$ & & & & $\begin{array}{c}0.0004 \\
(0.0007)\end{array}$ & $\begin{array}{c}0.0003 \\
(0.0008)\end{array}$ \\
\hline $\begin{array}{l}\text { Displaced } \\
\text { population }\end{array}$ & & & & & $\begin{array}{c}0.00001 \\
(0.00001)\end{array}$ \\
\hline No. obs & 95 & 95 & 95 & 95 & 94 \\
\hline
\end{tabular}

Notes: Figures in the parentheses are standard error

* Significant at the $10 \%$ level, ** Significant at the $5 \%$ level and *** Significant at the $1 \%$ level

violence are concentrated in areas of low development and production, demonstrating that in these areas, there is a deficiency in the control of violence.

Variables of market labour, measured as the unemployment rate and the number of employments per industry, show that a higher unemployment rate decreases the effectiveness of the control of violence, whereas a higher number of employments per industry increases the effectiveness of the control of violence. Economic problems generate increases in unemployment and underemployment, which are seen as impacting violence (Kambon and Henderson 2009; Weyland 2003; Frühling et al. 2003). These results are important in the development of different macroeconomic policies that promote the increase of employment through directed investment and government programmes, with effects on economic growth and decreases in violence.

Poverty measured as unsatisfied basic needs show that higher unsatisfied basic needs lower the effectiveness of the control of violence. Several studies have indicated a direct link between violence and poverty because the violence generates a loss of livelihoods, unemployment, displacement and changes in household composition, all of which are determinants of poverty (CICS 2005). Moreover, violence is associated with the destruction of infrastructure and social services, decreases in private and public investments, which generate a considerable impact on the economic position of both people and households due to the loss of assets, limited access to essential commodities and disruption or loss of livelihoods, which lead to increases in the levels of poverty of population (Justino 2006).

Education measured as coverage show a positive impact on the effectiveness of the control of violence, indicating that education plays an important role in the decrease and control of violence. In the Colombian case, Barrera and Ibañez (2004) have shown that 
Table 5 Results of MLE regressions for explaining effectiveness of the control of violence in Colombian Departments

\begin{tabular}{lccccc}
\hline Parameter & {$[1]$} & {$[2]$} & {$[3]$} & {$[4]$} & {$[5]$} \\
\hline Constant & $0.995^{* * *}$ & $1.546^{* * *}$ & $1.416^{* * *}$ & $1.637 * * *$ & $1.575^{* * *}$ \\
& $(0.111)$ & $(0.477)$ & $(0.480)$ & $(0.463)$ & $(0.471)$ \\
Political violence & $-0.030^{* *}$ & $-0.030^{* *}$ & $-0.026^{* *}$ & -0.015 & -0.015 \\
& $(0.012)$ & $(0.012)$ & $(0.012)$ & $(0.012)$ & $(0.012)$ \\
GDP & $3.41 \mathrm{e}-08^{* * * *}$ & $2.90 \mathrm{e}-08^{* * *}$ & $3.06 \mathrm{e}-08^{* * * *}$ & $4.08 \mathrm{e}-08^{* * *}$ & $4.29 \mathrm{e}-08^{* * *}$ \\
& $(1.10 \mathrm{e}-08)$ & $(1.14 \mathrm{e}-08)$ & $(1.14 \mathrm{e}-08)$ & $(1.13 \mathrm{e}-08)$ & $(1.17 \mathrm{e}-08)$ \\
Education & 0.048 & 0.058 & 0.061 & $0.067 *$ & $0.066^{*}$ \\
& $(0.040)$ & $(0.040)$ & $(0.039)$ & $(0.037)$ & $(0.037)$ \\
Unemployment rate & $-0.101^{* *}$ & $-0.124 * *$ & $-0.118^{* *}$ & -0.065 & -0.062 \\
& $(0.045)$ & $(0.049)$ & $(0.049)$ & $(0.049)$ & $(0.049)$ \\
Unsatisfied basic needs & & -0.127 & -0.097 & -0.046 & -0.050 \\
& & $(0.106)$ & $(0.107)$ & $(0.103)$ & $(0.103)$ \\
Hectares cultivated with & & & $-8.19 \mathrm{e}-06^{*}$ & $-4.16 \mathrm{e}-06$ & $-4.38 \mathrm{e}-06$ \\
coca & & & $(4.82 \mathrm{e}-06)$ & $(4.80 \mathrm{e}-06)$ & $(4.80 \mathrm{e}-06)$ \\
Displaced population & & & & $-0.070^{* * *}$ & $-0.071^{* * *}$ \\
GINI & & & & $(0.018)$ & $(0.018)$ \\
No. obs & & & & & -0.207 \\
& & & & & $(0.338)$
\end{tabular}

Notes: Figures in the parentheses are standard error

* Significant at the $10 \%$ level, ** Significant at the 5\% level and *** Significant at the $1 \%$ level

another economic cost of violence is the decrease of the human capital stock by the reduction in investments in human capital.

Another factor analysed is the displaced population, which shows a negative and significant coefficient, implying that departments with a higher displaced population show lower effectiveness in the control of violence. This result concurs with Kirchhoff and Ibañez's (2001) demonstration of the role of violence and perceptions of insecurity in the displaced population in the Colombian context. Moreover, the data on displacement show that violence, armed conflict, drug trafficking and the search for better living conditions have generated a displacement of population in recent decades (UN 2006).

The results of the Gini index indicate that higher inequality in land ownership generates a lower effectiveness of the control of violence. In Colombia, violence is considered the important development limitation that affects economic growth and productivity and decreases the government's capacity to reduce inequality and the exclusion of the rural and urban populations. Likewise, at the institutional level, it generates both high levels of impunity within the justice system and a lack of social investments (WB 2000).

Hectares cultivated with coca have a negative coefficient, indicating that a lower area cultivated with coca leads to a higher effectiveness of the control of violence. The increase of drug production and trafficking in recent decades in Colombia has intensified guerrilla and paramilitary violence and has worsened political and economic conditions in the country. Likewise, poverty in the countryside and a lack of government control in many areas have allowed the increase of drug production, generating violence in the different Colombian regions (UN 2006; Bagley 2001). 
Collective homicides have a negative coefficient, implying that departments with higher number of collective homicides experience a lower effectiveness of the control of violence. Restrepo et al. (2003) show that several large collective homicide cases in Colombia have occurred in regions where the degree of institutional development is precarious and the extent of government military operations is constrained by a lack of material resources and difficulties of geography.

In Colombian departments with high level of violence, GDP and education have positive effects on effectiveness of control of violence, whereas political violence, unemployment rate, unsatisfied basic needs, hectares cultivated with coca, displaced population and GINI have negative effects on effectiveness of control of violence. The main variables that determined an effectiveness of control of violence are GDP, unemployment rate, education and displaced population.

In Colombian departments with middle level of violence, education and employments per industry have positive effects on effectiveness of control of violence, whereas unsatisfied basic needs, political violence, GINI, hectares cultivated with coca, unemployment rate and displaced population have negative effects on effectiveness of control of violence. The main variable that determined an effectiveness of control of violence is political violence, whereas the other variables have not statistically significant effects.

In Colombian departments with low level of violence, GDP, education and employment per industry have positive effects on effectiveness of control of violence, whereas unemployment rate, unsatisfied basic needs, collective homicides, hectares cultivated with coca and displaced population have negative effects on effectiveness of control of violence. The main variable that determined an effectiveness of control of violence are GDP and unemployment rate, whereas the other variables have not statistically significant effects.

In whole Colombian departments, GDP and education have positive effects on effectiveness of control of violence, whereas unemployment rate, political violence, unsatisfied basic needs, hectares cultivated with coca, displaced population and GINI have negative effects on effectiveness of control of violence. The main variable that determined an effectiveness of control of violence are GDP, political violence, unemployment rate, and displaced population.

All of the findings of this paper are of particular interest for the formulation and development of policies against violence, taking into account that organised forms of violence, such as drug trafficking, corrupt and impede an adequate administration of justice. Moreover, violence decreases social investments, generating alterations in services such as health, police, and education, which in the long run lead to a deterioration of faith in the government's capacity, which should become an incentive to further violence.

\section{Conclusions}

In this paper, the effectiveness of the control of violence in 32 Colombian departments was compared using DEA with 7 performance attributes. Using panel data from 1993 to 2007, we find that there exist considerable differences in the effectiveness of the control of violence across Colombian departments. The results of DEA analysis indicate that the effectiveness of the control of violence is on average $73 \%$ for departments with a high level of violence, $80 \%$ for departments with a middle level of violence and $72 \%$ for departments with a low level of violence, indicating that departments with a middle level of violence show the best performance, whereas departments with a low level of violence show the worst performance in the control violence. 
The regression results show that the effectiveness of the control of violence is negatively associated with political violence, collective homicide cases and victims, unemployment rate, unsatisfied basic needs, displaced population, the GINI index, and hectares cultivated with coca, indicating that an increase in these factors decreases the effectiveness of the control of violence. However, the gross domestic product, education, and the number of employments per industry are positively associated with the effectiveness of the control of violence, meaning that an increase in these variables improves the effectiveness of the control of violence. These results indicate that economic development is a key factor to decrease violence because better social investments generate more opportunities that lead to economic growth, productivity and security for the population, whereas a lower social investment decreases faith in the government's capacity, motivating violence. Therefore, Colombian government ought to develop policies that strengthen social investment as a strategy to decrease violence and increase economic growth across Colombian departments.

DEA is not a new quantitative technique and has been used in research over the last decade. Therefore, the contribution of the research is to show the application of DEA to analyse the effectiveness of the control of violence across Colombian departments. In this exploratory research, we demonstrate that DEA can provide theoretical and practical insights that other techniques cannot in studies of violence and its control.

Acknowledgments The author would like to thank Prof. Dr. Stephan Klasen, Dr. Marcela Ibanez and participants of the 15th Annual Meeting of the Latin American and Caribbean Economic Association (LACEA (November 11-13, 2010)), 7th International Conference Developments in Economic Theory and Policy the University of Cambridge and University of the Basque Country (Bilbao, July 1-2, 2010), and the referees for their helpful suggestions and comments. The author is grateful for the support provided by Deutscher Akademischer Austausch Dients (DAAD), the University of Göttingen and the University of La Salle. Any remaining errors are the responsibility of the author.

Open Access This article is distributed under the terms of the Creative Commons Attribution Noncommercial License which permits any noncommercial use, distribution, and reproduction in any medium, provided the original author(s) and source are credited.

\section{References}

Adler, N., Yazhemsky, E., \& Tarverdyan, R. (2009). A framework to measure the relative socio-economic performance of developing countries. Socio-Economic Planning Sciences. doi:10.1016/j.seps.2009. 08.001 .

Ali, A., \& Seiford, L. (1990). Translation invariance in data envelopment analysis. Operations Research Letters, 9, 403-405.

Bagley, B. (2001). Drug trafficking, political violence and U.S. policy in Colombia in the 1990s. Coral Gables: School of International Studies, University of Miami.

Banker, R., Charnes, A., \& Cooper, W. (1984). Some models for estimating technical and scale efficiencies in data envelopment analysis. Management Science, 30, 1078-1092.

Banker, R. D., \& Natarajan, R. (2008). Evaluating contextual variables affecting productivity using data envelopment analysis. Operations Research, 56, 48-58.

Barrera, F., \& Ibañez, A. (2004). Does violence reduce investment in education? A theoretical and empirical approach. DOCUMENTO CEDE No. 002382. http://economia.uniandes.edu.co/publicaciones/d200427.pdf.

Becker, G. (1968). Crime and punishment: An economic approach. Journal of Political Economy, 76, 169217.

Bodea, C., \& Elbadawi, I. (2008). Political violence and economic growth. Policy Research Working Paper 4692, The World Bank, Development Research Group, Macroeconomics and Growth Team. 
Boix, C. (2008). Economic roots of civil wars and revolutions in the contemporary world. World Politics, $60,390-437$.

Bourguignon, F., Nuñez, J., \& Sanchez, F. (2002). What part of the income distribution does matter for explaining crime? The case of Colombia. Working paper 2003-04, Delta and World Bank, Paris and CEDE, Universidad de los Andes, Bogota.

Bowlin, W. (1987). Evaluating the efficiency of US Air Force real-property maintenance activities. Journal of Operational Research Society, 38, 127-135.

Bowlin, W. (1998). Measuring performance: An introduction to data envelopment analysis (DEA). Journal of Cost Analysis, 3, 3-27.

Burgoon, B. (2006). On welfare and terror. Social welfare policies and political-economic roots of terrorism. Journal of Conflict Resolution, 50, 176-203.

Butler, T., \& Johnson, W. (1997). Efficiency evaluation of Michigan prisons using data envelopment analysis. Criminal Justice Review, 22, 1-15.

Caves, D., Christensen, L., \& Diewert, E. (1982). The economic theory of index numbers of the measurement of input, output and productivity. Econometrica, 50, 1393-1414.

Centre for International Cooperation and Security (CICS). (2005). The impact of armed violence on poverty and development. Full report of the Armed Violence and Poverty Initiative. Department of Peace Studies, University of Bradford, UK.

Charnes, A., Clark, T., Cooper W., \& Golany, B. (1985). A developmental study of data envelopment analysis in measuring the efficiency of maintenance units in U. S. Air Forces. In R. Thompson \& R. M. Thrall (Eds.), Annals of Operational Research, 2, 95-112.

Charnes, A., Cooper, W., \& Lewin, A. (1994). Data envelopment analysis: Theory, methodology and applications. Boston: Kluwer.

Charnes, A., Cooper, W., \& Rhodes, E. (1978). Measuring efficiency of decision making units. European Journal of Operational Research, 2, 429-444.

Clunan, A., \& Trinkunas, H. (2010). Ungoverned spaces. Alternatives to state authority in an era of softened sovereignty. Stanford: Stanford University Press.

Collier, P. (2007). The bottom billion: Why the poorest countries are failing and what can be done about it. Oxford: Oxford University Press.

Collier, P., \& Hoeffler, A. (2004). Murder by numbers: Socio-economic determinants of homicide and civil war. Department of Economics, University of Oxford. CSAE WPS/2004-10.

Cooper, W., Seiford, L., \& Tone, K. (2000). Data envelopment analysis: A comprehensive text with models, applications, references. Boston, MA: Kluwer Academic Publishers.

Cotte, A. (2007). Growth, inequality and poverty: An analysis of the violence in Colombia, Bogotá, Universidad de La Salle. Available at SSRN http://ssrn.com/abstract=1012487.

Despotis, G. (2005). Measuring human development via data envelopment analysis: The case of Asia and the Pacific. Omega, 33, 385-390.

Despotis, D., Stamati, L., \& Smirlis, Y. (2009). Data envelopment analysis with nonlinear virtual inputs and outputs. European Journal of Operational Research, 202, 604-613.

Farrel, M. (1957). The measurement of productive efficiency. Journal of the Royal Statistical Society, A CXX(Part 3), 253-290.

Frühling, H., Tulchin, J., \& Golding, H. (2003). Crime and violence in Latin America: Citizen security, democracy, and the state. Washington, DC: Woodrow Wilson Center Press.

Garcia, I. (2007). Evaluating the effectiveness of the Spanish police force through data envelopment analysis. European Journal of Law and Economics, 23, 43-57.

Geneva Declaration Secretariat (GDS). (2008). Global burden of armed violence and development. http:// www.genevadeclaration.org/fileadmin/docs/Global-Burden-of-Armed-Violence-full-report.pdf.

Golany, B., \& Thore, S. (1997). The economic and social performance of nations: Efficiency and returns to scale. Socio-Economic Planning Sciences, 31, 191-204.

Greene, O., \& Bourne, M. (2005). Armed violence and conflict assessments. Briefing Paper, Centre for international cooperation and security, University of Bradford. www.bradford.ac.uk/acad/cics/ publications/AVPI/briefing.

Grun, R. (2008). Household investment under violence-The Colombian case. Policy Research Working Paper 4713, The World Bank, Middle East and North Africa Region, Human Development Group.

Habibov, N., \& Fan, L. (2009). Comparing and contrasting poverty reduction performance of social welfare programs across jurisdictions in Canada using data envelopment analysis (DEA): An exploratory study of the era of devolution. Evaluation and Program Planning. doi:10.1016/j.evalprogplan.2009.10.006.

Holmes, J., De Pineres, S., \& Curtin, K. (2007). A sub-national study of insurgency: FARC violence in the 1990s. Studies in Conflict and Terrorism, 30, 249-265. 
Holmes, J., Gutiérrez, S., \& Curtin, K. (2002). Drugs, violence and development in Colombia: A department level analysis. University of Texas at Dallas, Latin American Politics and Society.

Justino, P. (2006). On the links between violent conflict and chronic poverty: How much do we really know? Institute of Development Studies, at the University of Sussex. Chronic Poverty Research Centre. CPRC Working Paper 61.

Kambon, A., \& Henderson, G. (2009). Exploring policy linkages between poverty, crime and violence: A look at three Caribbean states. Economic Comission for Latin American and the Caribbean, Studies and Perspectives Series, United Nations publication.

Kenneth, C., Land, C., Lovell, K., \& Thore, S. (1994). Productive efficiency under capitalism and state socialism: An empirical inquiry using chance-constrained data envelopment analysis. Technological Forecasting and Social Change, 46, 139-152.

Kirchhoff, S., \& Ibañez, A. (2001). Displacement due to violence in Colombia: Determinants and consequences at the household level. ZEF-Discussion papers on development policy No. 41 .

Lamb, R. (2007). Ungoverned areas and threats from safe havens. Final Report of the Ungoverned Areas Project. Prepared for the Office of the Under Secretary of Defence for Policy.

López, J., Fernández, S., \& Morales, M. (2007). Application of the skill DEA (data envelopment analysis) in the determination of efficiency of centers of costs of production. Scientia et Technica, 37, 395-400. (In Spanish).

MacQueen, J. (1967). Some methods for classification and analysis of multivariate observations. Proceedings of 5th Berkeley Symposium on Mathematical Statistics and Probability. Berkeley, University of California Press, 1, 281-297.

Mahlberg, B., \& Obersteiner, M. (2001). Remeasuring the HDI by data envelopement analysis. Interim Report IR-01-069, International Institute for Applied Systems Analysis.

Malul, M., Hadad, Y., \& Ben-Yair, A. (2009). Measuring and ranking of economic, environmental and social efficiency of countries. International Journal of Social Economics, 36, 832-843.

Martínez, H., Medina, C., \& Steiner, R. (2001). Violence, inequality, poverty and drug prohibition in Colombia. CEDE, Universidad de Los Andes.

McDonald, J. (2009). Using least squares and tobit in second stage DEA efficiency analyses. European Journal of Operational Research, 197, 792-798.

Organisation for Economic Co-operation and Development (OECD). (2009). Conflict and fragility armed violence reduction: Enabling development. www.oecd.org.

Pardo, C. (2009). Energy efficiency development in the German and Colombian energy intensive sectors: A non-parametric analysis. Energy and Sustainability, II, 499-511. WIT Transactions on Ecology and the Environment.

Pardo, C. (2010). Energy efficiency development in German and Colombian non-energy-intensive sectors: A non-parametric analysis. Energy efficiency. doi:10.1007/s12053-010-9078-2.

Pombo, C., \& Taborda, R. (2006). Performance and efficiency in Colombia's power distribution system: Effects of the 1994 reform. Energy Economics, 28, 339-369.

Raab, R., \& Habib, E. (2007). A productivity growth accounting approach to the ranking of developing and developed nations. The International Journal of Accounting, 42, 396-415.

Raab, R., Kotamraju, P., \& Haag, S. (2000). Efficient provision of child quality of life in less developed countries: Conventional development indexes versus a programming approach to development indexes. Socio Economic Planning Sciences, 34, 51-67.

Ramanathan, R. (2003). An introduction to data envelopment analysis: A tool for performance measurement. Thousand Oaks, CA: Sage Publication.

Ramanathan, R. (2006). Evaluating the comparative performance of countries of the Middle East and North Africa: A DEA application. Socio-Economic Planning Sciences, 40, 156-167.

Ray, C. (2004). Data envelopment analysis: Theory and techniques for economics and operations research. Cambridge: Cambridge University Press.

Restrepo, J., Spagat, M., \& Vargas, J. (2003). The dynamics of the Colombian civil conflict: A new data set. Royal Holloway University of London Royal. Discussion Papers in Economics No. 03/12.

Restrepo, M., \& Villegas, G. (2007). Ranking Colombian research groups applying data envelopment analysis. Journal of Engineering faculty of Antioquia University, 42, 105-119. (In Spanish).

Rubio, M. (2001). Violence and conflict in the nineties. Coyuntura Social, 22, May. (In Spanish).

Sanchez, F., \& Nuñez, J. (2001). Determinants of violent crime in a highly violent country: Colombian case. Documento CEDE 2001-02 (In Spanish).

Smith, P. (1997). Model misspecification in data envelopment analysis. Annals of Operations Research, 73, 233-252.

Somarriba, N., \& Pena, B. (2009). Synthetic indicators of quality of life in Europe. Social Indicators Research, 94, 115-133. 
Stewart, R. (2008). Horizontal inequalities and conflict. Understanding Group Violence in Multiethnic Societies. London: Palgrave Macmillan.

Sun, S. (2002). Measuring the relative efficiency of police precincts using data envelopment analysis. SocioEconomic Planning Sciences, 36, 51-71.

Tulkens, H., \& Eeckaut, V. (1995). Non-parametric efficiency, progress and regress measures for panel data: Methodological aspects. European Journal of Operational Research, 80, 474-499.

United Nations (UN). (2006). Colombia, coca cultivation survey. Office on drugs and crime. www.unodc.org/pdf/andean/Colombia_coca_survey_2005_eng.pdf.

Verma, A., \& Gavirneni, S. (2006). Measuring police efficiency in India: An application of data envelopment analysis. Policing: An International Journal of Police Strategies and Management, 29, 125-145.

Weyland, K. (2003). Political repercussions of crime and violence in Latin America. An essay for the conference on culture and peace: Violence, politics, and representation in the Americas. University of Texas at Austin.

Wooldridge, J. (2001). Econometric analysis of cross section and panel data. Cambridge, MA and London, England: The MIT Press.

World Bank (WB). (2000). Violence in Colombia. Building sustainable peace and social capital. World Bank country studies.

World Health organisation (WHO). (2002). World report on violence and health. http://www.who.int/ violence_injury_prevention/violence/world_report/en/Full\%20WRVH\%20.pdf.

World Organization Against Torture (WOAT). (2005). Poverty, inequality and violence: The economic, social and cultural root causes of violence. A human rights perspective. www.omct.org/pdf/ESCR/. 